\title{
応用微生物学, 回顧と展望
}

日進月歩の分子生物学は生命の謎をつぎつぎに解明し, 今や遺伝子操 作によって人間は生物を積極的に变革できるまでになろうとしている。 そしてこの新しい学問と長い歴史を持つ応用微生物学との融合は人類に 微生物利用の様々な可能性を提示している。将来, 䁔造の分野にもこの 息吹きが取り入れられ，新たな展開がなされることも決して夢ではない。

今回は新年でもあり，このような新しい課題をかかえた応用微生物学 の将来について, 微生物遗伝学の権威でおられる筆者に歴史的背景をふ まえたお考えを述へていただいた。

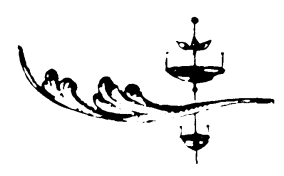

\section{[1]}

1 昨年（1976）の 4 月から9月までの間, 東大教養学 部で, “微生物学の 300 年”という講義をした。この題 目を選んだのは, 第 1 に, この年がレーウェンフックが 彼の私製の顕微鏡で細菌らしいものを初めて観察してか ら約 300 年, コッホが脾脱㾝菌の純粋分離に成功, パス ッールが䤙酵の概念を確立してから約 100 年にあたり, わたくしなりにそれを記念するためであった。第 2 は, 教養学部の学生に微生物学を教える場合, かなり初歩的 なことから教えなければならず，それには歴史を話すこ とが最もわかりやすいだろらと考えたからである。第 3 は, わたくし自身, 分子生物学といら進歩の激しい分野 に身を投じて以来，過去を振り返る余裕がなかったが， 停年を間近に控えて過去への郷愁がでてきたことによ る。

講義はレーウェンフックに始まり遺伝子操作で終った が，この講義はわたくしにいろいろなことを教えてくれ た。それは, 学生に歴史を教えるとなると, 事柄の羅列 たとえば重要発見の年代史を示すだけでは駄目で，その 背景に触れなければならない。すなわち体系化が必要で ある。わたくしは，わたくしなりに体系化を試みたが， いまそれをここで述べようというのではない。未来を占 らとなると過去, 現在とのつながりが必要なので, 講義 のときに述べたことの一端を披露して出発点としたいわ けである。

\section{[2]}

応用微生物学の始祖がパスッールであることには異議 がないことと思う。しかし, 学としての微生物学が確立

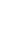

したのは, 顕微鏡の解像力が 1,000 倍近くに達し, 高圧 隇菌法が開発され，純粋分離ならびに培責法の確立した 1880 年頃のことではないだろらか。以後, 微生物学は 3つの流れをとったように思う。第 1 は, 病原菌の発見 を中心とする医学微生物学の発達であり, 第 2 は, 産業 との結びつきを中心とする農学微生物学の発達である。 この分岐は，ほぼ 1890 年頃になされ，それがたまたま わが国に西欧の微生物学が移入された明治初期に相当す るので, 医学微生物学は医学部で, 農学微生物学は農学 部でといら現在もな招継承されている形のものとなって しまった。わたくしが第 3 の流れといらのは, 微生物を 生物学の立場から見る理学微生物学のことで, この学問 はブフナー兄弟によるチマーゼ (酵素) の発見を契機と して発達したが，それは 1900 年以後のことで，そのと きには既にわが国では医学微生物学, 農学微生物学の分 化が括こなわれており, 当時の理学系の人達の微生物軽 視と相俟って, 理学微生物学としては固定しなかった。 強いていえば, 微生物代謝学の流れはあったが, 理学部 に生化学講座が出来るようになったのは, ずいぶんあと のことである。

さて応用微生物学であるが，学としての微生物学がわ が国に入ってきたのは 1880 年頃のことである。従っ て，世界的に見ても出発はさして遅れていない。この学 問が日本の産業と結びつくとすると，その接触点が日本 の古来からの醇造業である清酒, 味噌, 醬油であるこ と,さらにはカビであったことは誰しもが考えるとお りである。1970 年にわたくしは圾口先生と共著で, “Applied Microbiology in Japan; An Outline of its Historical Development and Characteristics” といら 論文を畫いたが，その冒頭で, “パスッール以後応用 微 
生物学は多様化し, オランダとロシアにおいては土壤微 生物学として, デンマークとドイッに扔いては醸造徽生 物学として, さらにスイスにおいては酪農微生物学とし て土着した”と記した。これは坂口先生のメモをわたく しが英訳したものであるが，もしもわが国に土着の応用 微生物学があるとしたら, それはカビの微生物学という ことになる。

わが国に拈けるカビの微生物学は, 古在先生, 高峯先 生, 高橋先生, 斎藤先生, 藪田先生, 坂口先生, 田宮先 生という先覚者の手によって世界でも独得の研究分野を 形成した (この間に打ける日本人学者の貢献は J.W. Foster 著 “Chemical Activities of Fungi (1949)” に 一部紹介されているが, 日本人研究者による調查研究が 欲しい)。そしてその成果が清酒酾造法の近代化等につ ながったが，一般的にいって1910年から 1940 年までの 世界の応用微生物学は漸進的であったといえる。このこ とは医学微生物学についてもいえ, この間の花形はむし ろ微生物代謝学であったとい党そらである。

\section{[3]}

わたくしは, 1940 年までの空用微生物学を前期と呼 んでいる。以後，こんにちまでが中期であるが，わたく

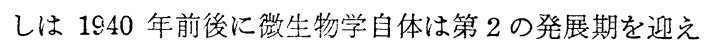
たと考える。その主導力の第 1 は, 抗生物質の登場であ る。抗生物質登場の背景は, S. A. Waksman 著 “The Antibiotic Era”にくわしいが, この抗生物質の登場が 微生物学界全般を活気づけた。事実, 抗生物質の発見に よっていわゆる伝染病は駆遂され, The Golden Age of Chemotherapy となった。第 2 は, 微生物遺伝学の登場 で, 一般には 1941 年にアメリカのビードルとテイタム がアカパンカビで生化学的突然变異株を分離した時点を 出発点とする。この微生物遗伝学は基礎微生物そのもの を代謝学から特異性究昭の学問へと転換させ, 当時勃興 したウイルス学 (バクテリオファージ学) の発達と相俟 って分子生物学へと關花した。微生物遗伝学 発達の背 景, 特に生化学とのドッキングについては別の機会に述 べたいと思う。

このような情勢変化が応用微生物学に影響しない管が ない。その第1の表われが密開タンクを用いる動的培養 形式の確立で，それまでにアルコール発酵，アセトン・ ブタノール発酵の前例があったとはい方, 発酵生産方式 の近代化といら意味では両者の間に大きな隔りがある。 事実, その後に発達したアミノ酸発酵などる抗生物質形 式に負らところが大きい。第 2 は突然变異株の採用であ る。それ以前においては, 微生物による生産は天然分離 株にたよっていた。ところが抗生物質の登場は微生物株
に突然変異を与えれば収量の増大してくれることを教え てくれた。また, 微生物遺伝学の登場は微生物のつくる 生産物の質の転換の出来ることを教えてくれた。わが国 で開発されたアミノ酸発酵, ヌクレオチド発酵がそれに 相当し, そこでは一つの菌株が突然变異の誘発により多 面的に利用されている。また，アミノ酸発酵などにおい ては量の增強もなされたわけであるが，そこでは分子生 物学で発達した制御理論に負らところが大きい。

動的発醭形式の採用, 突然变異株の利用, 制御理論の 活用が戦後の微生物生産を特長づける大きな柱である が，特長はそれだけではない。たとえば，原料転換があ る。すなわち, 戦後の発酵工業の一部においては, 糖質 の代りに炭化水素を原料とする新生産形式が採られるよ らになった。この生産は, 炭化水素を原料に微生物菌体 すなわちシングルセルプロティンをつくる方向と，アル コールや醋酸のような低分子化合物からアミノ酸や有機 酸をつくる方向に分れるが, 後者はわが国の研究者によ って開発されたといってよさそらである。それなら，こ の原料転換の原動力となったものはなにか。世界の食糧 事情が一つの要因であることはわかるが，それ以上の分 析はまだしていない。ただ，わたくしが大学を卒業した 当時 (194i), 坂口先生はカビを用いるとエチルアルコ ールからクエン酸, フマール酸, コージ酸のような有機 酸がつくられることを研究しておられ，わたくしもそれ を分担したことを思いだす。

原料転換はをた，発醅概念の転換を意味する。すなわ ち, 従来の発醭は高分子化合物たとえばデンプンや糖か ら低分子のアルコールなどのできることを意味した。と ころが, 現在ではアルコールからより高分子化合物がつ くられ, 場合によっては多桾類, 核酸の合成も可能であ る。わたくしは，前述した 1 菌株の多面的利用と発酵概 念の転換は, 応用微生物学を離れて一般微生物学の立場 に立っても歴史上特筡されるべきものと考兄る。

\section{[4]}

わたくしは, 現在は中期の終り, 終期に入る前夜と考 えている。しかし，期を分つとなるとそれなりの原動力 が必要である。それがなにかで展望に入るわけである が，頭の中ではいろいろなことが考兄られる。(1)原料 転換がいま一歩進んで空気 (炭酸ガス, 窒素) の利用に なる場合, (2)生産物が食糧, 医薬, 工業原料から離れ て水素などのエネルギー原料になる場合，（3）微生物種 がカビ, 酵母, バクテリアから離れて藻類や原虫に移る 場合, (4)微生物酵素の利用が菌体内酵素から離れて無 細胞系または固定化の形で利用される場合（いわゆるバ イオリアクター) などである。しかし，わたくしはこ 
こでは基碟生物学の流れの方から考えてみたいと思う。 基礎生物学が現在鋭意研究している対象に, 細胞分裂 の問題がある。この研究がさらに発展して微生物の生育 を制御することになったとさ，当然のこととしてその余 恵は㐫用微生物学に及ぶ。しかしながら，その余恵がぞ のよらな形で現われてくるかはいまのところ予測できな い。いま一つの学問的流れは, 分子遺伝学 $\rightarrow$ 分子育種学 の流れである。この流れを，わたくしは3つに分けて考 える。第 1 は，現在既に半分確立されかけている遗伝子 操作（遺伝子工学, 組換光 DNA) である。この技術が 応用微生物学にどのような影響を与兄るかは，范る程度 の確率をむって予言できる。その第 1 は, 微生物生産の 幅を一段と広めるであろらということである。周知のよ らに，現在では，異種の生物の DNA（遗伝子）を試験 管内組換え法と形質転換法で大腸菌の中に入れることが 可能である。この場合, 異種の生物は, カビ, 酵母, 細 菌, ウイルス, 動物, 植物, さらに合成 DNA でもよ い。しかも，高等生物のそれらを除き，注入された遺伝 子は大腸菌内でその機能を発揮して目的のものをつく る。すると, このことは微生物生産においては一つの革 命である。なぜなら，いままでの微生物株利用は，突然 变異法があるとはい光，その微生物株が元来持っている 能力の範囲内のことであった。ところが遺伝子操作法に よれば，異種しかもまったく種族の異なる生物の能力を も大腸菌价ンプットして利用することができる。すな わち, 大腸菌で全生物界の能力（情報）が利用できるわ けである。ある人は，この形式による生産をバクテリオ ファクチャー (bacteriofacture) といったが，マニュフ アクチャーに代るバクテリオフアクチャーの時代が来な いとはいえない。

遺伝子操作の第 2 の特長は, 微生物生産の量の增大に も有效であることである。遺伝子操作において遗伝子の 運搬体として利用されるのはプラスミド，ファージとい 万細胞内寄生因子で，これらはある条件下では数十分の 間に細胞あたり数百個に増殖する。一般に生産量は該当 する遺伝子の細胞内数に比例するので生産量もそれだけ 増すことが予想され，このことはトリプトファン合成酵 素の生産で実証された。な拉，さきに次代には微生物株 転換が括こるかも知れないと書いたが，ここで利用して いるプラスミド，ファージはウイルスレベルのもので， 微生物の利用は既にウイルス時代に入っているわ汁であ る。なお，進歩は上に述べた試験管組換えを中心とする 遺伝子操作に限らない。プラスミド,トランスポゾンを 利用する細胞内遗伝子操作, プロトプラスト融合, 試験 管内突然変異も同じょうに重要であるが, 他に書いた(発 酵と工業, 12 月号) ので省略する。

\section{[5]}

遺伝子操作が分子生物学の発展の延長線上の産物であ ることは上に述べたとおりであるが，最近の分子生物学 の発達の中には, 遺伝子操作以外にも将来応用微生物学 に大きな影響を与えそらな萠芽がいくつか見出される。 その一つは, DNA 化学の進歩である。 3 年活ど前に DNA の化学構造決定法が確立され, 現在では小さなウイルス DNA（約 3,000 ヌクレオチド）に扮いてはその全溝造 が解明され, 細菌 DNA においてもその増殖に必要な部 分の構造がわかってきた。きた一方, DNA の化学合咸 法も確立されて扮り， ヌクレオチド数 100 位のものであ ったら合成が可能である。そして事実, 化学構造のわか った遺伝子（DNA）についてはそれが化学合成され，乙 かも遗伝子操作法で大腸菌内に注入されて目的とする生 産物をつくることまで証明されている。ここまでは現実 であるが，これを延長するとどういうことになるか。わ たくしは，細胞内で自己増殖する寄生体（プラスミドな ど）が化学合成される時期はさして遠くないと考える。 プラスミドの合成自体は生物の合成とはいえないが，こ のようなものが合成された場合, 遺伝子操作法の㐫用範 囲は一段と広くなる。現在は大腸菌中心に研究がなされ ているが，いずれはカビ，酵母滴した寄生体も合成さ れるかも知れないからである。

その第 2 は, 分子生物学と進化学との結びつきである。 進化学は, いままで比較生物学的方法で研究され, 実験 室内で再現することは不可能とされていた。ところが， 分子生物学のらち基礎学の方は, 現在, 微生物を用いて 進化の要因解明と実験室的証明の方向を目指している。 要因となったのはトロンスポゾン $(2,000 〜 3,000$ ヌクレ オチド対）の発見などで，この因子は種間，場合によっ ては属間を転移する。従って, 進化を突然変異の蓄積と 見る従来の見解に対しては大きな衝撃であるだけでな く, 進化が実験室内で研究できるかも知れないという希 望を与えた。実験進化学となると，そこには新楮が生れ る。すなわちこの点で応用微生物学と結びつくわけで, 応用微生物学は以上述べた 3 つの方法, すなわち, (1) 遺伝子操作法による新種, (2) 合成 DNAによる新種, (3)進化研究の過程で生れる新種を中心に将来大きく摇 れる可能性を秘めている。そして，これがわたくしがさ き現在は応用微生物学はその歴史において後期汸入る 前夜にあるといった根拠でもある。

\section{$[6]$}

以上, 学問の流れの面からこれからの応用溦生物学を 展望した。しかし, 応用微生物学の将来を方向づけるの 
は，学問の進歩だけではない。すくなくとも，10 年ほ ど前までは, 学問の進歩が同時に産業の進歩であった。 しかし, 科学自体は 1970 年頃を境に変貌した。それ は, 評価（アセスメント）を加えながら科学は進歩させ るべきものであるといら立場である。上に述べた新株に よる生産などは当然その評価の対象になるもので，その 評価によって将来像が変ってくる。評価のプラス面は, 人類が現在かかえている諸問題, たとえば食糧問題, 工 ネルギー問題, 資源問題などを解決するのに微生物利用 工業が大きく貢献するであろらという期待である。これ に対してのマイナス面は，不測の事態がおこるという不 安であろう。この両面がどこで調和をとられるかは予測 を許さないが，わたくしは原子力がたどったと同じよう
な道を歩みそうな気がする。すなわち，人工株により炭 酸固定, 窒素固定, 水素発生等が可能となったときに は，国または世界的機関が関与して，その監督と責任の もとに生産が行なわれるであろらといら予想である。こ れは夢というのには余りにも抢そろしい展望であるが， 応用微生物学, 応用徽生物工業に, 政治や興論が介入し てくることは，いまから覚悟しておかなければならな い。わたくしがさきに述べた学術的展望の背景には，こ のような一般情勢があるわけで, 学術的展望即未来の予 测でないことをここでお断りしておきたいと思う。

応用微生物学の一側面だけを虫謂してしまったが，専 攻がこの方面であるのでお許し願いたい。

\section{＜会告 > 研究報告投稿規定の一部改正について}

本誌は伝統的な特色として, 論解説などの一般記事とともに試験研究報告 を併載しておりますが, 近年の科学技術の発達により, このよらな情報伝達 は益々要求されるところとなっております。そこで本誌では, 試験研究記事 について内容をより一層充害させたいと考兄，従来の投稿規定の一部を次の ように改正しましたので，これを厳守の上御投稿下さるょうお願いいたしま 9े。

報文の長さは図・表・文献・欧文要旨を含めて印刷面 6 頁以内とする。 